\title{
Double Infections of the Invasive Ladybird Harmonia axyridis
}

\begin{abstract}
Michiel D. de Groot ${ }^{1,2 *}$ and Danny Haelewaters ${ }^{1,3,4 *}$
${ }^{1}$ Research Group Mycology, Department of Biology, Ghent University, Ghent, Belgium, ${ }^{2}$ Research Institute for Nature and Forest (INBO), Brussels, Belgium, ${ }^{3}$ Faculty of Science, University of South Bohemia, České Budějovice, Czechia, ${ }^{4}$ Institute of Entomology, Biology Centre of the Czech Academy of Sciences, České Budějovice, Czechia
\end{abstract}

The dramatic spread of invasive alien species over the past century is considered to be an important threat to ecosystems worldwide. The harlequin ladybird, Harmonia axyridis, from eastern Asia, is considered to be one of the most invasive species. Originally introduced across the world as a biological control agent against crop pests owing to its voracious appetite and hardiness, those same qualities have made $H$. axyridis an invader that is difficult to eradicate. Harmonia axyridis has proven resilient against a variety of pathogens that have negative effects on other coccinellids. However, little research has examined the effects of simultaneous infections of multiple natural enemies on $\mathrm{H}$. axyridis. Here we present the available information on such double infections on $H$. axyridis, and discuss further research directions in this area.

Keywords: biocontrol, ecology, entomology, integrative pest management, invasion biology, parasitology

\section{OPEN ACCESS}

Edited by:

Brett K. Sandercock,

Norwegian Institute for Nature

Research (NINA), Norway

Reviewed by:

Ryan Schmid,

Ecdysis Foundation, United States

*Correspondence:

Michiel D. de Groot michielddegroot@gmail.com

Danny Haelewaters danny.haelewaters@gmail.com

Specialty section:

This article was submitted to Population, Community,

and Ecosystem Dynamics,

a section of the journal

Frontiers in Ecology and Evolution

Received: 11 August 2021

Accepted: 10 January 2022

Published: 31 January 2022

Citation:

de Groot MD and Haelewaters D

(2022) Double Infections of the

Invasive Ladybird Harmonia axyridis.

Front. Ecol. Evol. 10:756972.

doi: 10.3389/fevo.2022.756972

\section{INTRODUCTION}

The introduction and dramatic spread of non-native species is seen as a significant environmental disturbance threatening ecosystems around the world (Mooney and Cleland, 2001; Simberloff and Gibbons, 2004). Human activity enables species to reach and establish themselves in regions outside their native range, known as biological invasions (Vitousek et al., 1996; Mack et al., 2000). Environmentally problematic species are increasing globally, even in areas that are traditionally seen as sources rather than targets of alien species, such as Europe (Hulme et al., 2009). Global trade and human movement exacerbate the rate of alien invaders establishing themselves in new environments, and this method of distribution is projected to accelerate in the future (Levine and D'Antonio, 2003; Pfliegler et al., 2018). Some invasive species have considerable negative environmental and socio-economic effects, leading to mounting efforts to mitigate the damage (Vilà et al., 2010).

One of the posited explanations for the success of invaders in new environments is the enemy release hypothesis (Keane and Crawley, 2002; Colautti et al., 2004; Liu and Stiling, 2006; Roy et al., 2011a). The enemy release hypothesis proposes that population growth of invasive species results from release from their natural enemies that did not co-evolve in the new geographic location with them. This is beneficial for the invasive species on two fronts: first, they are not regulated by specialists, and second, their direct competitors of similar ecological guilds do have specialist enemies. Over time, population dynamics will be affected by evolutionary processes and the amount of natural enemies of the invasive species can increase (Brändle et al., 2008; Schilthuizen et al., 2016; Haelewaters et al., 2017), but not necessarily in time before the ecosystem is harmed (Geschke, 2019).

The harlequin ladybird, Harmonia axyridis (Pallas) (Arthropoda: Coleoptera, Coccinellidae), is a ladybird native to eastern Asia. Due to its resilience and voracious appetite, it was deemed very useful as a biological control agent against aphids, coccids, and other pests, and has been widely used in horticulture (Koch, 2003). Harmonia axyridis was introduced to protect 
crops in North America and later as an augmentative biocontrol in Europe, but it has now spread at an explosive rate to every continent except Australia and Antarctica over the past 30 years (Brown et al., 2011; Roy et al., 2016; Camacho-Cervantes et al., 2017; Hiller and Haelewaters, 2019). The same qualities that make $H$. axyridis a successful biocontrol agent also make it an effective intraguild predator. Whereas $H$. axyridis in its native range reached an equilibrium with its co-evolved guild of predators, in its exotic range it is in direct competition with populations of native predators, as the enemy release hypothesis would predict (Pell et al., 2008).

Harmonia axyridis has a negative effect not only on native insects, such as causing local ladybird populations to decline (Mizell, 2007; Roy et al., 2012), but also on food production and human health (Koch, 2003; Pickering et al., 2004; Koch and Galvan, 2008). It has been described as one of the "worst" invasive alien species of Europe (Nentwig et al., 2018). The International Union for Conservation of Nature (IUCN) established a Ladybird Specialist Group to identify species that are threatened and to develop conservation management strategies to counteract factors leading to high extinction risk. New methods of $H$. axyridis control must be assessed for the IUCN and similar groups to succeed in their plans to protect threatened species. In assessing how invasive species like $H$. axyridis can be controlled, it is important to determine the natural enemies of $H$. axyridis, how they spread, and which role they may have in regulating invasive populations of $H$. axyridis.

The search for natural enemies of $H$. axyridis has identified a variety of pathogens, parasites, and parasitoids affecting the ladybird, including bacteria, protozoans, fungi, nematodes, mites, wasps, and flies (Ceryngier et al., 2012, 2018; Haelewaters et al., 2017). Most of these natural enemies are generalists for coccinellid species or other insects. Part of $H$. axyridis' competitive success may be explained by its high resistance to such generalist enemies; $H$. axyridis has a relatively greater efficiency of its immune system, giving it robust and flexible defenses that surpass other competing ladybirds in the same region (Roy et al., 2008, 2011b; Vilcinskas et al., 2013; Gegner et al., 2018; Fincham et al., 2019). The immune system of $H$. axyridis is two-layered-it combines constitutive chemical defenses effective against a variety of bacteria as well as a wide range of antimicrobial peptides that are a result of multiple gene duplication events after speciation (Vilcinskas et al., 2013). Additionally, $H$. axyridis possesses strong alkaloid chemical defenses against predators and pathogens, which give it a foul smell and taste. These $H$. axyridis-specific alkaloids have been found to be more toxic compared to other coccinellids (Röhrich et al., 2011; Sloggett et al., 2011).

While local natural enemies of ladybirds have started using $H$. axyridis as a new host in places where it is invasive (Raakvan den Berg et al., 2014; Knapp et al., 2019), some invasive populations of $H$. axyridis may be only rarely infected (Dudek et al., 2017; Romero et al., 2020). As a result, these enemies of $H$. axyridis only have limited biocontrol potential for controlling invasive populations on their own, and some may actually have more adverse effects on locally native species than on $H$. axyridis (Riddick, 2010; Haelewaters et al., 2017; Ceryngier et al., 2018).
However, with this many potential natural enemies affecting $H$. axyridis and the species being so widespread, there might be combinations of pathogens, parasites, or parasitoids that have an adverse effect on the invasive populations. Here, we inventorize previously described double infections of $H$. axyridis and their effects, where known (Table $\mathbf{1}$ ).

\section{DOUBLE INFECTIONS}

Natural enemies impact their hosts' fitness in a variety of ways, such as increasing mortality, decreasing fecundity, and increasing susceptibility to parasites, pathogens, predators, or chemical agents. Insects are susceptible to infection by many different enemies, and simultaneous infections are anticipated to be common in the wild. In attempting to control invasive species, the additive effects of multiple infections can be a way to increase the efficiency of integrated pest management (IPM) programmes (Jabbour et al., 2011; Zindel et al., 2011). However, interactions between infecting species are difficult to predict, and can have conflicting results (Figure 1). For example, use of two species of natural fungal pathogens to combat the leaf-cutter ant Acromyrmex lundii (GuérinMéneville) (Arthropoda: Hymenoptera, Formicidae), an agricultural pest in the Neotropics, caused the two species of fungi to suppress each other rather than the pest (Folgarait et al., 2011). In a another example, when the invasive garden ant Lasius neglectus Van Loon, Boomsma \& Andrasfalvy (Formicidae) was exposed to the mortal entomopathogen Metarhizium brunneum Petch (Ascomycota: Hypocreales, Calvicipitaceae) after infection by Laboulbenia formicarum Thaxt. (Ascomycota: Laboulbeniales, Laboulbeniaceae), the upregulated immunological and behavioral responses caused fewer fatalities from the secondary infection than either fungus on its own (Konrad et al., 2015). Such complex interactions therefore warrant exhaustive review and experimentation, both by surveys in the wild and mortality experiments in laboratory settings, especially for species with hardy defense systems, such as $H$. axyridis.

The endosymbiotic bacterium Spiroplasma (Tenericutes: Entomoplasmatales, Spiroplasmataceae) infects the gut of hemolymph of a large variety of insects, with effects ranging from mutualistic to parasitic (Hackett and Clark, 1989). In a subset of insects including ladybirds, Spiroplasma causes so-called male-killing by destroying eggs fertilized by Y-bearing sperm, causing extremely female-biased offspring (Zakharov et al., 1999; Harumoto and Lemaitre, 2018). In H. axyridis, Spiroplasma also reduces body size, embryo survival, and adult lifespan in infected females (Majerus, 2002). Infection by Spiroplasma only seems to occur in native populations of $H$. axyridis; thus far infections have not been reported in populations in areas where they are invasive (Goryacheva et al., 2017). A survey of Spiroplasma strains in H. axyridis from Japan and eastern Russia-both in its native range-revealed the majority of beetles that were infected by Spiroplasma to be infected by multiple strains (88\%) (Goryacheva et al., 2018). However, the exact 
TABLE 1 | Known simultaneous infections by multiple natural enemies on Harmonia axyridis and their effect on the host.

\begin{tabular}{|c|c|c|c|c|c|}
\hline Species 1 & Species 2 & Field or lab & Locality & Effect of co-infection & Reference(s) \\
\hline Spiroplasma strain 1 & Spiroplasma strain 2 & Field & Japan, Russia & $\mathrm{N} / \mathrm{A}$ & Goryacheva et al., 2018 \\
\hline Hesperomyces virescens & $\begin{array}{l}\text { Parasitylenchus } \\
\text { bifurcatus }\end{array}$ & Field & $\begin{array}{c}\text { Germany, Netherlands, } \\
\text { Caucasus }\end{array}$ & $\mathrm{N} / \mathrm{A}$ & $\begin{array}{c}\text { Herz and Kleespies, 2012; } \\
\text { Raak-van den Berg et al., } \\
\text { 2014; Orlova-Bienkowskaja } \\
\text { et al., } 2018\end{array}$ \\
\hline Hesperomyces virescens & $\begin{array}{l}\text { Coccipolipus } \\
\text { hippodamiae }\end{array}$ & Field, Lab & Austria, United States & Increased mortality & $\begin{array}{c}\text { Christian, 2002; Riddick, } \\
2010\end{array}$ \\
\hline Hesperomyces virescens & Beauvaria bassiana & Lab & $\begin{array}{l}\text { United Kingdom, } \\
\text { United States }\end{array}$ & No increased mortality & $\begin{array}{c}\text { Berry, 2017; Haelewaters } \\
\text { et al., } 2020\end{array}$ \\
\hline Hesperomyces virescens & Metarhizium brunneum & $\mathrm{Lab}$ & United States & No increased mortality & Haelewaters et al., 2020 \\
\hline
\end{tabular}

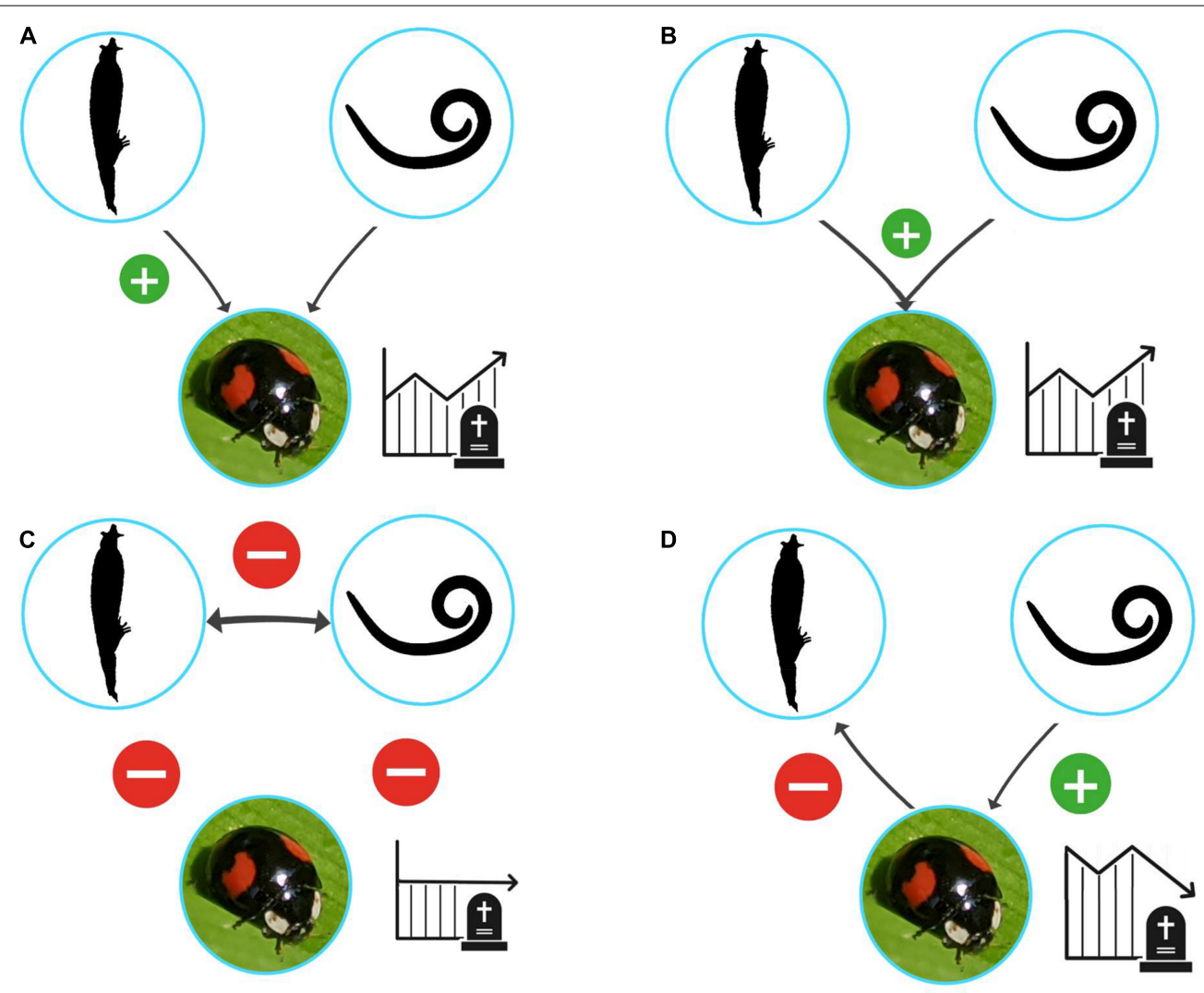

FIGURE 1 | Conceptual overview of potential effects of co-infection by two natural enemies on the fitness of a given host. (A) The co-infection causes no additional decrease in fitness. (B) There is an additive effect of the second enemy, causing a stronger decrease in fitness upon co-infection. (C) The infecting species neutralize each other, causing no increase or decrease in fitness. (D) One natural enemy causes a prophylactic effect in the host, preventing a secondary infection from taking hold, increasing the host's fitness. Photo: Harmonia axyridis (iNaturalist \#53583172).

biological consequences of multiple infections as opposed to a single infection remain unclear.

The fungus Hesperomyces virescens Thaxt. (Ascomycota: Laboulbeniales, Laboulbeniaceae) is an obligate ectoparasite infecting adult ladybirds of over thirty species (Haelewaters et al., 2017). Recent integrative taxonomic analyses have revealed that $H$. virescens is in fact made up of many different species, each specifically adapted to its individual host (Haelewaters et al., 2018; Haelewaters and De Kesel, 2020; Crous et al., 2021). $H$. virescens completes its entire lifecycle on its living host; sexual spores divide mitotically to produce yellowish, multicellular, three-dimensional structures called thalli on the outside of any part of the host's body. These thalli penetrate the host's cuticle via a rhizoidal haustorium (De Kesel, 2011; Haelewaters et al., 2017). Hesperomyces virescens has been found to co-infect $H$. axyridis hosts alongside the nematode Parasitylenchus bifurcatus Poinar \& Steenberg (Nematoda: Tylenchida, Allantonematidae) in Germany (Herz and Kleespies, 2012), The Netherlands (Raak-van den Berg et al., 2014), and the Caucasus (Orlova-Bienkowskaja et al., 2018). Parasitylenchus bifurcatus is an obligate endoparasite specific to $H$. axyridis; these nematodes live, mate, and proliferate within the host. The method of transmission from host to host is unknown (Poinar and Steenberg, 2012). It was speculated from observations in the field that simultaneous infection by 
$H$. virescens and $P$. bifurcatus reduced survival rates of $H$. axyridis (Raak-van den Berg et al., 2014).

A different natural enemy to co-infect $H$. axyridis alongside $H$. virescens is the ectoparasitic mite Coccipolipus hippodamiae (McDaniel \& Moril) (Arthropoda: Acarina, Podapolipidae). Simultaneous infections by these two natural enemies have thus far been observed in Austria (Christian, 2001, 2002) and the United States (Riddick, 2010). Coccipolipus hippodamiae infection causes decreased fecundity, decreased egg viability, and increased mortality in a variety of coccinellid species (Webberley et al., 2004), but the exact biological mechanisms are still unknown. Transmission from one host to the next occurs similarly to $H$. virescens: through bodily contact during mating or overwintering (Knell and Webberley, 2004). Mortality from C. hippodamiae infection is especially high in overwintering males (Webberley et al., 2006). In a simulated winter experiment, $H$. axyridis individuals co-infected by both mites and the fungus died earlier than those infected by the fungus only (Riddick, 2010).

Hesperomyces virescens has also been used to co-infect $H$. axyridis individuals in a laboratory experiment together with Beauveria bassiana (Bals.-Criv.) Vuill. (Ascomycota: Hypocreales, Cordycipitaceae) and Metarhizium brunneum Petch (Sordariomycetes: Hypocreales, Calvicipitaceae) (Berry, 2017; Haelewaters et al., 2020). Beauveria bassiana is among the best studied of the coccinellid pathogenic fungi. Germinating spores penetrate the host's integument, which is followed by mycelial proliferation inside the host's body. The fungus feeds on the host while it is alive. Infection is usually fatal for the host; after its death $B$. bassiana becomes saprophytic and produces conidia for further transmission (Ceryngier et al., 2012). While $B$. bassiana is considered a major mortality factor for many coccinellids, $H$. axyridis has been shown to lose fecundity under laboratory conditions, but mortality was not increased (Roy et al., 2008). Experiments co-infecting $H$. axyridis with $H$. virescens together with either B. bassiana or M. brunneum have no increased mortality in comparison to infection with only $H$. virescens. In contrast, the North American-native ladybird Olla v-nigrum (Mulsant) (Arthropoda: Coleoptera, Coccinellidae) was more susceptible to B. bassiana after infection by $H$. virescens (Haelewaters et al., 2020). This differential susceptibility between the native and invasive species is in line with the enemy release hypothesis, which, as detailed above, predicts that invasive species are so successful in part because they are less susceptible to the local natural enemies compared to native species.

\section{DISCUSSION AND FUTURE DIRECTIONS}

The above inventory of various pathogens and parasites co-infecting $H$. axyridis illustrate the fundamental gaps in our understanding of how these species interact on an ecological level, and that little research examines multiple groups of pathogens at once. Despite $H$. axyridis being a widely studied model organism for invasion biology (Roy and Wajnberg, 2008), little is known about its natural enemies. Additionally, the relatively minor effects on fitness by its natural enemies, even in simultaneous infections, have underlined the resilience of this invasive alien species. Still, that does not mean looking at co-infections is a fruitless endeavor, with some simultaneous infection combinations proving mortal in laboratory experiments. The surface of this area of research has barely been scratched, and further studies are warranted.

In nature, individual hosts are frequently infected by multiple pathogens, parasites, or parasitoids. However, the effects on survival rate and usability of a combination of natural enemies as biocontrol often remains unclear. One way to improve biological control of invasive and pest species is to exploit the potentially additive function of co-infections. Therefore, we need to understand (i) what biotic and abiotic factors determine the likelihood of a co-infection on a host, (ii) what the exact biological mechanisms are that cause double infections to have an additive negative effect on host survival or fecundity, and (iii) the ways in which these interactions affect the local ecology and nontarget species.

This requires an approach that is neither a specifically pairwise interaction between two species, nor a much larger-scale population-level analysis. This includes network approaches seeking to illuminate intra- and interspecific interactions between hosts and their multiple enemies (Roy and Lawson Handley, 2012). These interactions will likely also vary under different conditions and on different spatial and temporal scales. For example, fungal ectoparasites of ladybirds have been shown to be more prevalent in urban environments (urban heat island effect; Welch et al., 2001), and simultaneous infection can be extremely localized (Raak-van den Berg et al., 2014). To not just take a shot in the dark, it is therefore useful to identify which combinations of co-infecting species already exist in nature, and draw surveys and experiments from there. Molecular data should prove enlightening for unraveling the interactions between hosts and their various natural enemieseven more so for host-parasite interactions, as parasites are often cryptic, hidden, or inside the host, and therefore difficult to track by traditional surveying methods (Hesketh et al., 2010). Another potentially valuable avenue for collecting data on novel host-parasite interactions is found in citizen science; monitoring websites such as iNaturalist can provide reports of new occurrences of interactions between a host and its parasites, and in new localities (Haelewaters et al., 2019). Citizen science projects monitoring $H$. axyridis such as the Lost Ladybug Project in the United States and the United Kingdom Ladybird Survey, among others, also generate image collections that can be screened for parasites (Fothergill et al., 2010; Brown et al., 2018; Werenkraut et al., 2020). Similarly, digitized museum collections can be screened for ectoparasites using a stereoscope relatively easily (Báthori et al., 2017; Haelewaters et al., 2017).

Harmonia axyridis makes for a powerful model organism, both as an invasive alien species and for the study of simultaneous infections by natural enemies. While spreading around the world, to every continent except Australia and Antarctica, H. axyridis may have brought its natural enemies with it and it has interacted with a wide range of locally native organisms. As a common factor among all those locations, this globetrotter ladybird makes for a great study subject on global ecological interactions. 


\section{AUTHOR CONTRIBUTIONS}

DH: conceptualization. MG: writing-original draft and visualization. MG and DH: writing-review and editing. Both authors have read and agreed to the published version of the manuscript.

\section{FUNDING}

DH is supported by the Research Foundation-Flanders (Junior Postdoctoral Fellowship 1206620N) and the Czech Science Foundation (grant 21-06446S).

\section{REFERENCES}

Báthori, F., Pfliegler, W. P., Zimmerman, C. U., and Tartally, A. (2017). Online image databases as multi-purpose resources: discovery of a new host ant of Rickia wasmannii Cavara (Ascomycota, Laboulbeniales) by screening AntWeb.org. J. Hymenopt. Res. 61, 85-94. doi: 10.3897/jhr.61.20255

Berry, K. M. (2017). The Role of Parasites in the Invasion Ecology of Harmonia Axyridis. Ph.D. thesis. Stirling: University of Stirling.

Brändle, M., Kühn, I., Klotz, S., Belle, C., and Brandl, R. (2008). Species richness of herbivores on exotic host plants increases with time since introduction of the host. Divers. Distrib. 14, 905-912. doi: 10.1111/j.1472-4642.2008. 00511.x

Brown, P. M., Roy, D. B., Harrower, C., Dean, H. J., Rorke, S. L., and Roy, H. E. (2018). Spread of a model invasive alien species, the harlequin ladybird Harmonia axyridis in Britain and Ireland. Sci. Data 5, 180239. doi: 10.1038/ sdata.2018.239

Brown, P. M., Thomas, C. E., Lombaert, E., Jeffries, D. L., Estoup, A., and Handley, L. J. L. (2011). The global spread of Harmonia axyridis (Coleoptera: Coccinellidae): distribution, dispersal and routes of invasion. BioControl 56, 623-641. doi: 10.1007/s10526-011-9379-1

Camacho-Cervantes, M., Ortega-Iturriaga, A., and Del-Val, E. (2017). From effective biocontrol agent to successful invader: the harlequin ladybird (Harmonia axyridis) as an example of good ideas that could go wrong. PeerJ 5, e3296. doi: 10.7717/peerj.3296

Ceryngier, P., Nedvěd, O., Grez, A. A., Riddick, E. W., Roy, H. E., San Martin, G., et al. (2018). Predators and parasitoids of the harlequin ladybird, Harmonia axyridis, in its native range and invaded areas. Biol. Invasions 20, 1009-1031. doi: 10.1007/s10530-017-1608-9

Ceryngier, P., Roy, H. E., and Poland, R. L. (2012). "Natural enemies of ladybird beetles," in Ecology and Behaviour of the Ladybird Beetles (Coccinellidae), eds I. Hodek, H. F. van Emden, and A. Honěk (London: John Wiley and Sons), 375-443. doi: 10.1002/9781118223208.ch8

Christian, E. (2001). The coccinellid parasite Hesperomyces virescens and further species of the order Laboulbeniales (Ascomycotina) new to Austria. Ann. Naturhist. Mus. Wien 103, 599-603.

Christian, E. (2002). On the distribution and bionomics of the ladybird parasite Coccipolipus hippodamiae (McDaniel \& Morrill, 1969) (Acari, Podapolipidae). Abh. Ber. Naturkundemus. Gorlitz 74, 9-14.

Colautti, R. I., Ricciardi, A., Grigorovich, I. A., and MacIsaac, H. J. (2004). Is invasion success explained by the enemy release hypothesis? Ecol. Lett. 7, 721-733. doi: 10.1111/j.1461-0248.2004.00616.x

Crous, P. W., Osieck, E. R., Jurjević, Ž., Boers, J., van Iperen, A. L., StarinkWillemse, M., et al. (2021). Fungal planet description sheets: 1284-1382. Persoonia 47, 178-374. doi: 10.3767/persoonia.2021.47.06

De Kesel, A. (2011). Hesperomyces (Laboulbeniales) and coccinellid hosts. Sterbeeckia 30, 32-37.

Dudek, K., Gwiazdowicz, D. J., and Tryjanowski, P. (2017). A “clean" alien species? Parasites of the invasive ladybird Harmonia axyridis (Coleoptera: Coccinellidae). Eur. J. Entomol. 114, 350-354. doi: 10.14411/eje.20 17.044

\section{ACKNOWLEDGMENTS}

The first author would like to thank the continually inspiring Menno Schilthuizen (Naturalis Biodiversity Center and Taxon Expeditions, Leiden, the Netherlands), whose suggestion of the second author as a supervisor has resulted in an extraordinarily interesting pandemic year. The second author wants to take the opportunity to thank Ted E. Cottrell (Agricultural Research Service, Southeastern Fruit and Tree Nut Research Laboratory, U.S. Department of Agriculture, Byron, Georgia) for his enduring generosity and mentorship since the spring of 2014 .

Fincham, W. N., Dunn, A. M., Brown, L. E., Hesketh, H., and Roy, H. E. (2019). Invasion success of a widespread invasive predator may be explained by a high predatory efficacy but may be influenced by pathogen infection. Biol. Invasions 21, 3545-3560. doi: 10.1007/s10530-019-02067-w

Folgarait, P., Gorosito, N., Poulsen, M., and Currie, C. R. (2011). Preliminary in vitro insights into the use of natural fungal pathogens of leaf-cutting ants as biocontrol agents. Curr. Microbiol. 63, 250-258. doi: 10.1007/s00284-0119944-y

Fothergill, K., Moore, W., Losey, J., Allee, L. L., and Smyth, R. R. (2010). First Arizona records of the multicolored Asian lady beetle, Harmonia axyridis (Pallas) (Coleoptera: Coccinellidae). Coleopterol. Bull. 64, 51-52. doi: 10.1649/ 0010-065X-64.1.51

Gegner, T., Carrau, T., Vilcinskas, A., and Lee, K.-Z. (2018). The infection of Harmonia axyridis by a parasitic nematode is mediated by entomopathogenic bacteria and triggers sex-specific host immune responses. Sci. Rep. 8, 15938. doi: 10.1038/s41598-018-34278-x

Geschke, J. (2019). Decrease in bat diversity points towards a potential threshold density for black cherry management: a case study from Germany. Plants 8, 320. doi: 10.3390/plants8090320

Goryacheva, I., Blekhman, A., Andrianov, B., Romanov, D., and Zakharov, I. (2018). Spiroplasma infection in Harmonia axyridis - Diversity and multiple infection. PLoS One 13, e0198190. doi: 10.1371/journal.pone.0198190

Goryacheva, I., Blekhman, A., Andrianov, B., and Zakharov, I. (2017). Heritable bacterial endosymbionts in native and invasive populations of Harmonia axyridis. Biol. Invasions 19, 493-502. doi: 10.1007/s10530-016-1298-8

Hackett, K. J., and Clark, T. B. (1989). "Ecology of spiroplasmas," in The Mycoplasmas. 5. Spiroplasmas, Acholeplasmas, and Mycoplasmas of Plants and Arthropods, eds R. F. Whitcomb and J. G. Tully (San Diego, CA: Academic Press), 113-200. doi: 10.1016/B978-0-12-078405-9.50012-4

Haelewaters, D., and De Kesel, A. (2020). Checklist of thallus-forming Laboulbeniomycetes from Belgium and the Netherlands, including Hesperomyces halyziae and Laboulbenia quarantenae spp. nov. MycoKeys 71, 23-86. doi: 10.3897/mycokeys.71.53421

Haelewaters, D., De Kesel, A., and Pfister, D. H. (2018). Integrative taxonomy reveals hidden species within a common fungal parasite of ladybirds. Sci. Rep. 8, 15966. doi: 10.1038/s41598-018-34319-5

Haelewaters, D., Hiller, T., Kemp, E. A., van Wielink, P. S., Shapiro-Ilan, D. I., Aime, M. C., et al. (2020). Mortality of native and invasive ladybirds co-infected by ectoparasitic and entomopathogenic fungi. PeerJ 8, e10110. doi: 10.7717/ peerj. 10110

Haelewaters, D., Hiller, T., Pan, F. Y., and Pan, J. Y. (2019). Tracking an ectoparasitic fungus of Harmonia axyridis in the USA using literature records and citizen science data. IOBC WPRS Bull. 145, 17-22.

Haelewaters, D., Zhao, S. Y., Clusella-Trullas, S., Cottrell, T. E., De Kesel, A., Fiedler, L., et al. (2017). Parasites of Harmonia axyridis: current research and perspectives. BioControl 62, 355-371. doi: 10.1007/s10526-016-9766-8

Harumoto, T., and Lemaitre, B. (2018). Male-killing toxin in a bacterial symbiont of Drosophila. Nature 557, 252-255. doi: 10.1038/s41586-018-0086-2

Herz, A., and Kleespies, R. G. (2012). Occurrence of natural enemies in different populations of the invasive ladybird Harmonia axyridis (Pallas, 1771) 
(Coleoptera, Coccinellidae) in Germany. Mitt. Dtsch. Ges. Allg. Angew. Entomol. $18,201-206$.

Hesketh, H., Roy, H. E., Eilenberg, J., Pell, J. K., and Hails, R. S. (2010). Challenges in modelling complexity of fungal entomopathogens in seminatural populations of insects. BioControl 55, 55-73. doi: 10.1007/s10526-0099249-2

Hiller, T., and Haelewaters, D. (2019). A case of silent invasion: citizen science confirms the presence of Harmonia axyridis (Coleoptera, Coccinellidae) in Central America. PLoS One 14, e0220082. doi: 10.1371/journal.pone.0220082

Hulme, P. E., Pyšek, P., Nentwig, W., and Vilà, M. (2009). Will threat of biological invasions unite the European Union? Science 324, 40-41. doi: 10.1126/science. 1171111

Jabbour, R., Crowder, D. W., Aultman, E. A., and Snyder, W. E. (2011). Entomopathogen biodiversity increases host mortality. Biol. Control 59, 277283. doi: 10.1016/j.biocontrol.2011.07.016

Keane, R. M., and Crawley, M. J. (2002). Exotic plant invasions and the enemy release hypothesis. Trends Ecol. Evol. 17, 164-170. doi: 10.1016/s0169-5347(02) 02499-0

Knapp, M., Řeřicha, M., Maršíková, S., Harabiš, F., Kadlec, T., Nedvěd, O., et al. (2019). Invasive host caught up with a native parasitoid: field data reveal high parasitism of Harmonia axyridis by Dinocampus coccinellae in Central Europe. Biol. Invasions 21, 2795-2802. doi: 10.1007/s10530-019-02027-4

Knell, R. J., and Webberley, K. M. (2004). Sexually transmitted diseases of insects: distribution, evolution, ecology and host behaviour. Biol. Rev. 79, 557-581. doi: $10.1017 /$ S1464793103006365

Koch, R. L. (2003). The multicolored Asian ladybird, Harmonia axyridis: a review of its biology, uses in biological control, and non-target impacts. J. Insect Sci. 3, 1-16. doi: 10.1673/031.003.3201

Koch, R. L., and Galvan, T. L. (2008). Bad side of a good beetle: the North American experience with Harmonia axyridis. BioControl 53, 23-35. doi: 10.1007/s10526007-9121-1

Konrad, M., Grasse, A. V., Tragust, S., and Cremer, S. (2015). Anti-pathogen protection versus survival costs mediated by an ectosymbiont in an ant host. Proc. R. Soc. B Biol. Sci. 282, 20141976. doi: 10.1098/rspb.2014.1976

Levine, J. M., and D'Antonio, C. M. (2003). Forecasting biological invasions with increasing international trade. Conserv. Biol. 17, 322-326. doi: 10.1046/j.15231739.2003.02038.x

Liu, H., and Stiling, P. (2006). Testing the enemy release hypothesis: a review and meta-analysis. Biol. Invasions 8, 1535-1545. doi: 10.1007/s10530-005-5845-y

Mack, R. N., Simberloff, D., Lonsdale, W. M., Evans, H., Clout, M., and Bazzaz, F. A. (2000). Biotic invasions: causes, epidemiology, global consequences, and control. Ecol. Appl. 10, 689-710. doi: 10.1890/1051-0761(2000)010[0689: bicegc]2.0.co;2

Majerus, T. M. O. (2002). The Evolutionary Genetics of Male-Killing in the Coccinellidae. Ph.D. thesis. Cambridge: University of Cambridge.

Mizell, R. F. III (2007). Impact of Harmonia axyridis (Coleoptera: Coccinellidea) on native arthropod predators on pecan and crape myrtle. Fla. Entomol. 90, 524-536.

Mooney, H. A., and Cleland, E. E. (2001). The evolutionary impact of invasive species. Proc. Natl. Acad. Sci. U.S.A. 98, 5446-5451. doi: 10.1073/pnas. 091093398

Nentwig, W., Bacher, S., Kumschick, S., Pyšek, P., and Vilà, M. (2018). More than "100 worst" alien species in Europe. Biol. Invasions 20, 1611-1621. doi: 10.1007/s10530-017-1651-6

Orlova-Bienkowskaja, M. J., Spiridonov, S. E., Butorina, N. N., and Bieńkowski, A. O. (2018). Coinvasion by the ladybird Harmonia axyridis (Coleoptera: Coccinellidae) and its parasites, Hesperomyces virescens (Ascomycota: Laboulbeniales) and Parasitylenchus bifurcatus (Nematoda: Tylenchida, Allantonematidae), in the Caucasus. PLoS One 13, e0202841. doi: 10.1371/journal.pone.0202841

Pell, J. K., Baverstock, J., Roy, H. E., Ware, R. L., and Majerus, M. E. N. (2008). Intraguild predation involving Harmonia axyridis: a review of current knowledge and future perspectives. BioControl 53, 147-168. doi: 10.1007/ s10526-007-9125-x

Pfliegler, W. P., Báthori, F., Wang, T. W., Tartally, A., and Haelewaters, D. (2018). Herpomyces ectoparasitic fungi (Ascomycota, Laboulbeniales) are globally distributed by their invasive cockroach hosts and through the pet trade industry. Mycologia 110, 39-46. doi: 10.1080/00275514.2017.1418567
Pickering, G., Lin, J., Riesen, R., Reynolds, A., Brindle, I., and Soleas, G. (2004). Influence of Harmonia axyridis on the sensory properties of white and red wine. American J. Enol. Vitic. 55, 153-159.

Poinar, G. O., and Steenberg, T. (2012). Parasitylenchus bifurcatus n. sp. (Tylenchida: Allantonematidae) parasitizing Harmonia axyridis (Coleoptera: Coccinellidae). Parasit. Vectors 5, 218. doi: 10.1186/1756-3305-5-218

Raak-van den Berg, C. L., van Wielink, P. S., de Jong, P. W., Gort, G., Haelewaters, D., Helder, J., et al. (2014). Invasive alien species under attack: natural enemies of Harmonia axyridis in the Netherlands. BioControl 59, 229-240. doi: 10.1007/ s10526-014-9561-3

Riddick, E. W. (2010). Ectoparasitic mite and fungus on an invasive lady beetle: parasite coexistence and influence on host survival. Bull. Insectol. 63, 13-20.

Röhrich, C. R., Ngwa, C. J., Wiesner, J., Schmidtberg, H., Degenkolb, T., Kollewe, C., et al. (2011). Harmonine, a defence compound from the harlequin ladybird, inhibits mycobacterial growth and demonstrates multi-stage antimalarial activity. Biol. Lett. 8, 308-311. doi: 10.1098/rsbl.2011.0760

Romero, V., Zaviezo, T., and Grez, A. A. (2020). The invasive coccinellid Harmonia axyridis (Coleoptera: Coccinellidae) is a less suitable host for parasitism than resident species. Int. J. Agric. Nat. Resour. 47, 312-323. doi: 10.7764/ijanr.v47i3. 2239

Roy, H., and Wajnberg, E. (2008). From biological control to invasion: the ladybird Harmonia axyridis as a model species. BioControl 53, 1-4. doi: 10.1007/s10526007-9127-8

Roy, H. E., Adriaens, T., Isaac, N. J., Kenis, M., Onkelinx, T., Martin, G. S., et al. (2012). Invasive alien predator causes rapid declines of native European ladybirds. Divers. Distrib. 18, 717-725. doi: 10.1111/j.1472-4642.2012.00883.x

Roy, H. E., Brown, P. M., Adriaens, T., Berkvens, N., Borges, I., Clusella-Trullas, S., et al. (2016). The harlequin ladybird, Harmonia axyridis: global perspectives on invasion history and ecology. Biol. Invasions 18, 997-1044. doi: 10.1007/s10530016-1077-6

Roy, H. E., Brown, P. M., Rothery, P., Ware, R. L., and Majerus, M. E. (2008). Interactions between the fungal pathogen Beauveria bassiana and three species of coccinellid: Harmonia axyridis, Coccinella septempunctata and Adalia bipunctata. BioControl 53, 265-276. doi: 10.1007/s10526-007-9122-0

Roy, H. E., and Lawson Handley, L. J. (2012). Networking: a community approach to invaders and their parasites. Funct. Ecol. 26, 1238-1248. doi: 10.1111/j.13652435.2012.02032.x

Roy, H. E., Lawson Handley, L.-J., Schönrogge, K., Poland, R. L., and Purse, B. V. (2011a). Can the enemy release hypothesis explain the success of invasive alien predators and parasitoids? BioControl 56, 451-468. doi: 10.1007/s10526-0119349-7

Roy, H. E., Rhule, E., Harding, S., Handley, L. J. L., Poland, R. L., Riddick, E. W., et al. (2011b). Living with the enemy: parasites and pathogens of the ladybird Harmonia axyridis. BioControl 56, 663-679. doi: 10.1007/s10526-011-9387-1

Schilthuizen, M., Pimenta, L. P. S., Lammers, Y., Steenbergen, P. J., Flohil, M., Beveridge, N. G., et al. (2016). Incorporation of an invasive plant into a native insect herbivore food web. PeerJ 4, e1954. doi: 10.7717/peerj.1954

Simberloff, D., and Gibbons, L. (2004). Now you see them, Now you don't! Population crashes of established introduced species. Biol. Invasions 6, 161-172. doi: 10.1023/B:BINV.0000022133.49752.46

Sloggett, J. J., Magro, A., Verheggen, F. J., Hemptinne, J. L., Hutchison, W. D., and Riddick, E. W. (2011). The chemical ecology of Harmonia axyridis. BioControl 56, 643-661. doi: 10.1007/s10526-011-9376-4

Vilà, M., Basnou, C., Pyšek, P., Josefsson, M., Genovesi, P., Gollasch, S., et al. (2010). How well do we understand the impacts of alien species on ecosystem services? A pan-European, cross-taxa assessment. Front. Ecol. Environ. 8, 135-144. doi: $10.1890 / 080083$

Vilcinskas, A., Mukherjee, K., and Vogel, H. (2013). Expansion of the antimicrobial peptide repertoire in the invasive ladybird Harmonia axyridis. Proc. R. Soc. B Biol. Sci. 280, 20122113. doi: 10.1098/rspb.2012.2113

Vitousek, P. M., D’Antonio, C. M., Loope, L. L., and Westbrooks, R. (1996). Biological invasions as global environmental change. Am. Sci. 84, 468-478.

Webberley, K. M., Buszko, J., Isham, V., and Hurst, G. D. (2006). Sexually transmitted disease epidemics in a natural insect population. J. Anim. Ecol. 75, 33-43. doi: 10.1111/j.1365-2656.2005.01020.x

Webberley, K. M., Hurst, G. D., Husband, R. W., Schulenburg, J. H. G., Sloggett, J. J., Isham, V., et al. (2004). Host reproduction and a sexually transmitted disease: causes and consequences of Coccipolipus hippodamiae distribution 
on coccinellid beetles. J. Anim. Ecol. 73, 1-10. doi: 10.1111/j.1365-2656.2004. 00769.x

Welch, V. L., Sloggett, J. J., Webberley, K. M., and Hurst, G. D. D. (2001). Short-range clinal variation in the prevalence of a sexually transmitted fungus associated with urbanisation. Ecol. Entomol. 26, 547-550. doi: 10.1046/j.13652311.2001.00352.x

Werenkraut, V., Baudino, F., and Roy, H. E. (2020). Citizen science reveals the distribution of the invasive harlequin ladybird (Harmonia axyridis Pallas) in Argentina. Biol. Invasions 22, 2915-2921. doi: 10.1007/s10530-02002312-7

Zakharov, I. A., Zinkevich, N. S., Shaǐkevich, E. V., Vysotskaia, L. V., ChM, D., and Majerus, M. E. (1999). Sex ratio and male killing in Siberian populations of Harmonia axyridis (Pass.). Genetika 35, 771-776.

Zindel, R., Gottlieb, Y., and Aebi, A. (2011). Arthropod symbioses: a neglected parameter in pest-and disease-control programmes. J. Appl. Ecol. 48, 864-872. doi: $10.1111 / j .1365-2664.2011 .01984 . x$
Conflict of Interest: The authors declare that the research was conducted in the absence of any commercial or financial relationships that could be construed as a potential conflict of interest.

Publisher's Note: All claims expressed in this article are solely those of the authors and do not necessarily represent those of their affiliated organizations, or those of the publisher, the editors and the reviewers. Any product that may be evaluated in this article, or claim that may be made by its manufacturer, is not guaranteed or endorsed by the publisher.

Copyright (C) 2022 de Groot and Haelewaters. This is an open-access article distributed under the terms of the Creative Commons Attribution License (CC BY). The use, distribution or reproduction in other forums is permitted, provided the original author(s) and the copyright owner(s) are credited and that the original publication in this journal is cited, in accordance with accepted academic practice. No use, distribution or reproduction is permitted which does not comply with these terms. 